\title{
WHO'S WHO
}

\section{Dan Chen, Dan-dan Huang}

\section{You-mei Lu: a Brief Biography}

\author{
You-mei Lu
}

\section{Professor}

Tsinghua University

Professor You-mei Lu was born in Shanghai in January 1934. In 1956, he graduated from East China Water Conservancy College, the predecessor of Hehai University of today. He, a great engineer, and a famous technologist and scientist in domestic water conservancy, is also a professor at Tsinghua University and Hehai University.

Professor Lu has long been engaged in construction technology and management of hydropower projects. He worked as vice minister of the Ministry of Water Resources and Electricity Industry, and vice minister of the Ministry of Energy

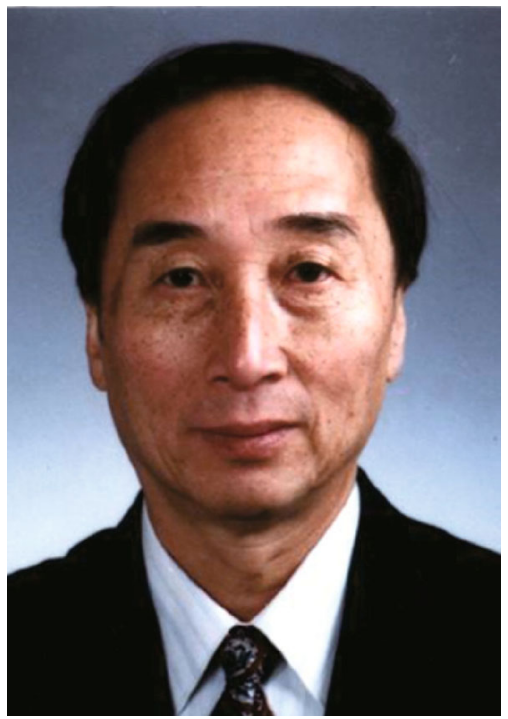
Industry, of the People's Republic of China; and he served as vice chairman of the State Council Three Gorges Project Construction Committee, general manager of the Three Gorges Project Corp of China, and chairman of the Great Dam Committee of China.

He participated in and chaired many hydropower construction projects, including the Liujia Gorge Project, the Yanguo Gorge Project, the Ankang Hydropower Plant, and the Longyang Gorge Project, which contributed greatly to the construction of hydropower projects in China. When he worked in the Ministry of Water Resources and Electricity Industry and the Ministry of Energy Industry, he took great efforts to promote the reform of the institutions of hydropower development and construction.

He was considered by many as the chief commander of the Three Gorges Project, because he led and participated in the construction of the most crucial ten years of the Three Gorges Project. He conducted research on engineering technology and engineering management, and made a series of strategic decisions to such technological and managerial problems in the Three Gorges Project as the overall layout, the scheme of the transportation construction, the diversion cofferdam engineering, the rapid construction of dams and the selection of large hydroelectric generating sets. He put forward a complete plan for quality control, investment control and diversified financing which included sub-project bidding, subproject management, "two-zero construction management goal" (zero quality accident, zero safety accident). He laid emphasis on the synchronous construction of the project and the environment. The Three Gorge Project has successfully begun water storage as a reservoir, energy production as a power plant and navigation as a water route, well verifying the positive value of Lu's research and strategic plan.

Professor $\mathrm{Lu}$ achieved much in engineering management theory and practice, and his achievements benefit from his diligence, and his will to confront with difficulties, especially his capacity to bear hardships and to stand hard work. It was reported that $\mathrm{Lu}$ stayed on the construction site with other scientists and technologists and conducted repeated experiments for all the projects he chaired.

Professor Lu authored many books and papers, the major one of which include: The Technologies in the Three Gorges Project; The Practice of the Construction and Management of the Three Gorges Project; The Three Gorges Dam Concrete Construction; The Three Gorges Project Improves the Eco-Environment of the Yangtze River; A Philosophical 
Analysis of the Three Gorges Project; The Social Responsibility of the Dam Engineering.

Professor Lu has been devoting himself to water conservancy construction and management in China for more than fifty years. His tremendous contributions have been unprecedented, helping China to build great water conservancy projects. It is not exaggerated to say that Professor $\mathrm{Lu}$ is one of the outstanding water conservancy experts in China.

He was elected as a member of the Chinese Academy of Engineering in 2003.

As a scholar, his profound knowledge, original idea, broad vision, rigorous scholarship and creativity have attracted many young students in the field of hydro engineering and engineering management. 